\title{
FAKTOR YANG BERHUBUNGAN DENGAN KUALITAS APLIKASI TRY OUT UJI KOMPETENSI BERBASIS EXCEL
}

\section{FACTORS RELATED TO THE QUALITY OF THE EXCEL-BASED APPLICATION TRY OUT COMPETENCE TEST}

\author{
Anas Tamsuri \\ Stikes Pamenang \\ Korespondensi : anastamsuri@gmail.com
}

\begin{abstract}
Abstrak
Uji Kompetensi merupakan salah satu kegiatan bagi tenaga kesehatan untuk dinyatakan kompeten sebagai tenaga kesehatan dan memastikan bahwa orang yang mendapatkan ijin tersebut telah mencapai standar minimum untuk diakui dalam menjalankan tugas dan kompeten dalam memberikan pelayanan secara aman dan legal. Namun demikian, ternyata angka kelulusan uji kompetensi tenaga perawat masih relatif rendah. Kesiapan dan manajemen strategis merupakan faktor yang penting untuk memperoleh tingkat kelulusan uji kompetensi yang tinggi. Uji coba (try out) uji kompetensi merupakan salah satu strategi yang dikembangkan dalam menyiapkan uji kompetensi. Salah satu media yang dapat digunakan untuk penyelenggaraan ujian try out adalah melalui penggunaan aplikasi berbasis Excel. Tujuan penelitian ini adalah untuk mengetahui faktor yang berhubungan dengan penilaian kualitas aplikasi try out uji kompetensi berbasis Excel.

Metode penelitian yang digunakan adalah metode survey (observasional). Populasi penelitian adalah peserta try out uji kompetensi yang diselenggarakan Aipviki Jawa Timur pada bulan Oktober 2020 yang mengisi kuesioner tentang kualitas aplikasi, sejumlah 174 orang. Sampel penelitian sejumlah 120 orang dipilih menggunakan pendekatan acak sederhana. Pengambilan data dengan menggunakan kuesioner dan analisis data dilakukan Uji Korelasi Spearman dengan $\alpha=5 \%$. Hasil penelitian menunjukkan bahwa bahwa tata letak, keterlihatan (visibility), pengenalan fitur, kelengkapan fitur dan kemudahan menggunakan fitur merupakan komponen yang berhubungan dengan penilaian individu terhadap kualitas aplikasi ujian online berbasis Excel.

Dari hasil penelitian, maka disarankan untuk dilakukan penelitian lebih lanjut untuk melihat aspek kualitas lain utamanya pada aspek correctness dan reliabilitas dari aplikasi ujian sebagai indikator apakah aplikasi ini dapat digunakan secara luas.
\end{abstract}

Kata kunci : Kualitas, Aplikasi Try Out, Uji Kompetensi

\begin{abstract}
Competency Test is one of the activities for health workers to be declared that they are competent as health workers and ensure that the person who gets the permit has reached the minimum standard to be recognized in carrying out their duties and they are competent in providing services safely and legally. However the passing rate of the nurse in competency test is still relatively low. Readiness and strategic management are important factors in obtaining a high passing rate of competency tests. try out for Competency test is one of the strategies developed in preparing competency tests. One of the media that can be used to administer try out exams is through the use of an Excel-based application. The purpose of this study was to determine the factors related to the quality assessment of the Excel-based competency test try out application.

The research method used was a survey method. The study population was participants in the competency test try out held by Aipviki East Java in October 2020 who filled out a questionnaire about the quality of the application, totaling 174 people. The research sample was 120 people, who selected using a simple random approach. The data collected used questionnaire and data analysis performed by Spearman Correlation Test with $\alpha=5 \%$.

The results showed that the layout, visibility, feature recognition, feature completeness and ease of use of features were components that were associated with individual perception on the quality of the Excel-based online exam application.
\end{abstract}


From the results of the study, it is advisable to carry out further research to see other quality aspects, especially the correctness and reliability aspects of the test application as an indicator of whether this application can be used widely.

Keyword: Quality, Try Out Application, Competence test

\section{Latar Belakang}

Uji Kompetensi merupakan salah satu kegiatan bagi tenaga kesehatan untuk dinyatakan kompeten sebagai tenaga kesehatan dan memastikan bahwa orang yang mendapatkan ijin tersebut telah mencapai standar minimum untuk diakui dalam menjalankan tugas dan kompeten dalam memberikan pelayanan secara aman dan legal (Oducado, R.M.F., \& Penuela, A.C. ; 2014). Namun demikian, ternyata angka kelulusan uji kompetensi tenaga perawat masih relatif rendah (Tamsuri, Anas \& Suryono, 2020). Diperkirakan masih terdapat $50 \%$ peserta uji kompetensi yang tidak dapat lulus uji kompetensi (Wardani, Yulia \& Mahayanti, Agnes, 2018).

Rendahnya angka kelulusan uji kompetensi memberikan dampak yang signifikan. Salah satunya adalah menyebabkan lulusan tidak dapat memperolah pekerjaan secara cepat dan menciptakan pengangguran baru. Lulusan baru dari pendidikan semestinya dapat mempergunakan ijazahnya untuk bekerja, namun untuk perawat diwajibkan untuk lulus uji kompetensi sebagai persyaratan untuk mendapatkan Surat Tanda Registrasi (STR) dan STR merupakan salah satu syarat untuk mendapatkan pekerjaan dalam keperawatan; dan karenanya ketidaklulusan uji kompetensi dapat menyebabkan kesempatan bagi lulusan perawat untuk bekerja menjadi terhambat (Tamsuri, Anas \& Suryono, 2020).

Mengingat bahwa uji kompetensi begitu krusial fungsinya untuk menentukan kelayakan seorang perawat dalam menjalankan profesi, maka penyiapan uji kompetensi sangat diperlukan agar mahasiswa atau peserta dapat lulus uji kompetensi dengan baik. Kesiapan dan manajemen strategis merupakan faktor yang penting untuk memperoleh tingkat kelulusan uji kompetensi yang tinggi (Wardani, Yulia \& Mahayanti, Agnes, 2018). Berbagai upaya dilakukan oleh Perguruan tinggi untuk menguatkan tingkat kesiapan mahasiswa dan atau lulusan agar dapat menghadapi uji kompetensi dengan baik, antara lain melalui pembekalan seperti review materi asuhan keperawatan secara berkelompok, melakukan review soal uji kompetensi, menghadirkan pembicara pakar atau pemateri dari luar perguruan tinggi untuk mendapatkan tips lulus uji kompetensi (Rahadian, 2018). Strategi lain yang dikembangkan dalam penyiapan uji kompetensi adalah dengan menyelenggarakan atau mengikuti uji coba (try out) uji kompetensi. Penelitian menunjukkan bahwa Try Out uji kompetensi memiliki pengaruh terhadap kelulusan uji kompetensi. Penelitian dari Hartina, dkk (2017) menunjukkan bahwa peserta program pendidikan Ners yang mengikuti Try Out uji kompetensi memiliki peluang untuk lulus lebih besar dibandingkan mereka yang tidak mengikuti Try Out. Wardani, Yulia \& Mahayanti, Agnes, (2018) dalam laporan penelitiannya juga menunjukkan hasil ujian try out uji kompetensi selama tiga tahun (2014-2016) memiliki trend yang serupa dengan hasil uji kompetensi yang sesungguhnya.

Dalam masa pandemi Covid 19, Pemerintah memberikan rambu-rambu untuk penerapan protokol kesehatan dalam rangka mencegah penyebaran dan penularan virus Corona di Indonesia. Berbagai aspek kehidupan ditata dan diatur, termasuk didalamnya adalah tentang penyelenggaraan pendidikan selama terjadinya wabah Covid 19. Berpijak pada edaran Lembaga Layanan Dikti wilayah VII nomor 578 tahun 2020 tertanggal 16 Maret 2020 tentang Pencegahan Corona Virus Disease (Covid 19) pada Perguruan Tinggi di Lingkungan LLDIkti Wilayah VII, maka proses penyelenggaraan pendidikan/ perkuliahan pada perguruan tinggi yang sebelumnya diselenggarakan dalam bentuk tatap muka langsung, digantikan dengan metoda daring. Pembelajaran diselenggarakan dengan metode belajar dari rumah (Study from Home), dan perguruan tinggi wajib menyiapkan dan menerapkan protokol kesehatan. Salah satu aspek yang juga digantikan adalah metoda evaluasi dan Try Out ujian kompetensi. Metode Try Out uji kompetensi yang diselenggarakan selama ini menggunakan metode kertas diganti dengan 
menggunakan metode jarak jauh. Penelitian dari Tamsuri, Anas \& Suryono (2020) yang melakukan try out uji kompetensi menggunakan aplikasi Google Form mendapatkan hasil ternyata $51 \%$ responden mengalami kendala dalam menggunakan aplikasi Google Form, utamanya kendala dalam penggunaan jaringan. Penelitian ini relevan dengan penelitian sebelumnya yang dilakukan oleh Septiawan, Fansuri (2020). Penelitian ini mendapati bahwa terdapat kesulitan melakukan test dengan Google Form. kendala yang dihadapi oleh peserta bukan pada kesulitan mengoperasikan aplikasi Google Form, sering terkendala sinyal internet dan membutuhkan biaya yang mahal adalah tantangan tersendiri dalam pembelajaran daring

Berpijak pada pemikiran diatas, maka penting untuk dikembangkan aplikasi ujian lain yang sederhana tidak memerlukan jaringan internet. Salah satu aplikasi yang dapat dikembangkan adalah menggunakan aplikasi Excel dengan Macro. Peneliti mengembangkan aplikasi ini untuk menyelenggarakan kegiatan ujian try out uji kompetensi sebagai bagian dari upaya menyiapkan lulusan dalam menghadapi uji kompetensi. Aplikasi Excel dengan Macro ini disusun dengan fitur keamanan akses soal, fitur limitasi user, fitur countdown (hitung mundur), dan fitur untuk mengecek progres pengerjaan soal.

Tujuan dari penelitian ini adalah untuk mengidentifikasi faktor yang mempengaruhi penilaian kualitas aplikasi Try Out berbasis Excel. Tujuan khusus dari penelitian ini adalah untuk mengetahui hubungan antara penilaian terhadap tata letak (X1), keterlihatan (visibility) fitur aplikasi (X2), kemudahan pengenalan / rekognisi fitur (X3), penilaian atas kelengkapan fitur (X4) serta penilaian atas tingkat kemudahan menjalankan aplikasi (X5) terhadap penilaian kualitas aplikasi (Y).

\section{Metode}

Penelitian ini merupakan jenis penelitian kuantitatif. Desain penelitian yang digunakan adalah Cross Sectional (potong lintang). Penelitian diselenggarakan sebagai bagian dari evaluasi atas penggunaan aplikasi Uji Kompetensi Berbasis Excel yang dikembangkan oleh peneliti dan diimplementasikan pada bulan Oktober 2020. Pengambilan data dilakukan pada pada tanggal 14 Oktober 2020 dan tanggal 21 Oktober 2020. Populasi dari penelitian ini adalah seluruh peserta ujian yang eligible menggunakan aplikasi dan mendapatkan kuesioner untuk pengukuran kualitas dari software, sejumlah 174 orang. Sampel penelitian ditetapkan dengan menggunakan Tabel penentuan sampel dari Isaac dan Michael, pada jumlah populasi 180 dengan $\alpha=5 \%$ ditetapkan jumlah sampel sebanyak 119 orang, atau dibulatkan menjadi 120 orang responden. Penentuan sampel dilakukan dengan teknik acak sederhana (simple random sampling) dengan menggunakan fasilitas bilangan acak dari Aplikasi Excel.

Variabel pada penelitian ini meliputi penilaian kualitas pada aplikasi sebagai variabel dependen, dan terdapat variabel penilaian tingkat kemudahan menjalankan aplikasi, kelengkapan fitur aplikasi, kemudahan pengenalan (rekognisi) fitur aplikasi, keterlihatan (visibility) fitur aplikasi dan penilaian tata letak (component placement) sebagai variabel independen. Pengolahan data dilakukan dengan pendekatan kuantitatif dengan menggunakan Excel. Data diolah dengan pendekatan shorting dan clearing data, selanjutnya dilakukan tabulasi dan disajikan dalam diagram. Analisis data dilakukan menggunakan uji korelasi Spearman dengan $\alpha=5 \%$. Analisis dilakukan dengan bantuan aplikasi SPSS versi 16.

\section{Hasil Penelitian}

1. Penilaian Responden terhadap tata letak fitur dan aplikasi

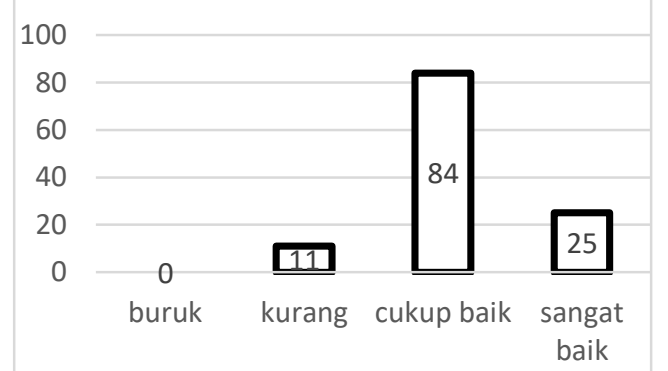

Gambar 1. Grafik Batang Penilaian Responden terhadap Tata Letak pada Aplikasi

Hasil penelitian menunjukkan bahwa sebagian besar responden menilai tata letak komponen aplikasi pada tingkat cukup baik. 
2. Penilaian Responden terhadap Keterlihatan (visibilitas) Aplikasi

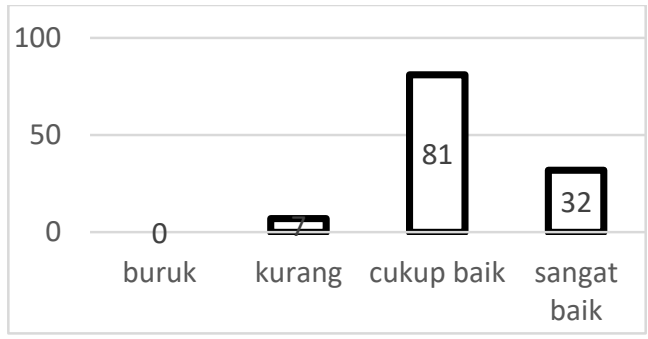

Gambar 2. Grafik Batang Penilaian Responden dalam menggunakan Aplikasi

Hasil penelitian menunjukkan bahwa sebagian besar responden menilai kemudahan dalam melihat bagian / komponen aplikasi pada tingkat cukup baik.

3. Kemudahan Responden dalam Mengenali Fitur Aplikasi

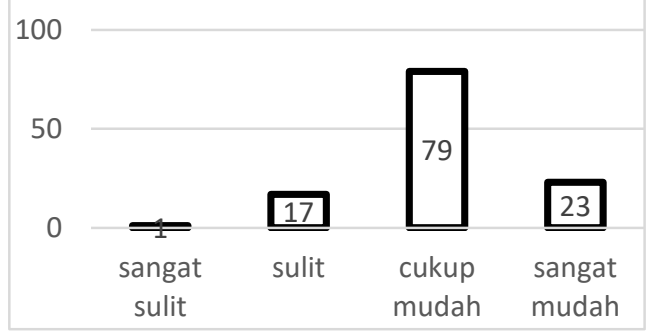

Gambar 3. Grafik Batang Penilaian Kemudahan Responden dalam Mengenal Fitur Aplikasi

Hasil penelitian menunjukkan bahwa sebagian besar responden menilai kemudahan mengenal fitur aplikasi pada tingkat cukup mudah.

4. Penilaian Responden terhadap Kelengkapan Fitur Aplikasi

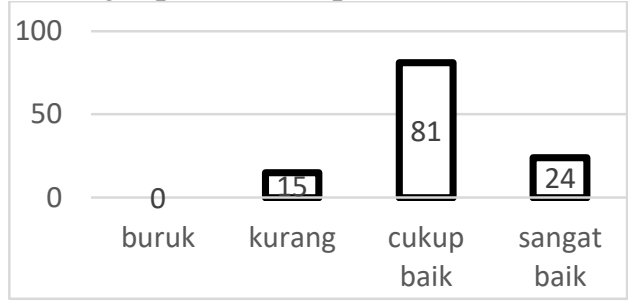

Gambar 4. Grafik Batang Penilaian Responden terhadap Kelengkapan Fitur Aplikasi

Hasil penelitian menunjukkan bahwa sebagian besar responden menilai kelengkapan fitur aplikasi pada tingkat cukup baik.

5. Penilaian Responden tentang Kemudahan Menggunakan Aplikasi

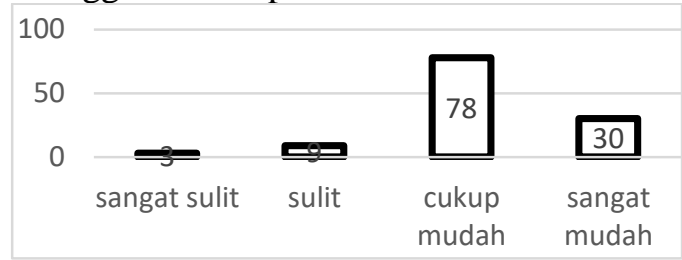

Gambar 5. Grafik Batang Penilaian Kemudahan Responden dalam menggunakan Aplikasi

Hasil penelitian menunjukkan bahwa sebagian besar responden menilai kemudahan menjalankan aplikasi pada tingkat cukup mudah.

6. Penilaian Responden terhadap Kualitas Aplikasi

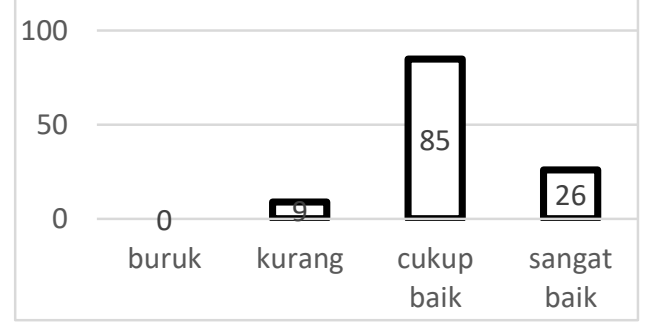

Gambar 6. Grafik Batang Penilaian Responden terhadap Kualitas Aplikasi

Hasil penelitian menunjukkan bahwa sebagian besar responden menilai kualitas aplikasi pada tingkat cukup baik.

7. Hubungan Faktor penilaian Responden Terhadap Tingkat Kemudahan Menjalankan Aplikasi, Kelengkapan Fitur Aplikasi, Kemudahan Pengenalan (Rekognisi) Fitur Aplikasi, Keterlihatan (Visibility) Fitur Aplikasi Dan Penilaian Tata Letak Terhadap Penilaian Atas Kualitas Aplikasi

Hasil uji korelasi Spearman diperoleh hubungan antar variabel sebagaimana tergambar pada tabel berikut ini:

Tabel 1. Korelasi antara faktor dependen dan independen

\begin{tabular}{|l|l|l|}
\hline Korelasi & $\begin{array}{l}\text { Signi } \\
\text { fikansi }\end{array}$ & $\begin{array}{l}\text { Koefisien } \\
\text { Korelasi }\end{array}$ \\
\hline $\begin{array}{l}\text { Kualitas dan } \\
\text { Tata Letak }\end{array}$ & 0,00 & 0,575 \\
\hline
\end{tabular}




\begin{tabular}{|l|l|l|}
\hline $\begin{array}{l}\text { Kualitas dan } \\
\text { Keterlihatan } \\
\text { (visibility) fitur }\end{array}$ & 0,00 & 0,563 \\
\hline $\begin{array}{l}\text { Kualitas dan } \\
\text { pengenalan fitur }\end{array}$ & 0,00 & 0,556 \\
\hline $\begin{array}{l}\text { Kualitas dan } \\
\text { kelengkapan } \\
\text { fitur }\end{array}$ & 0,00 & 0,384 \\
\hline $\begin{array}{l}\text { Kualitas dan } \\
\text { kemudahan } \\
\text { menggunakan } \\
\text { fitur }\end{array}$ & 0,02 & 0,212 \\
\hline
\end{tabular}

Dari hasil penelitian didapatkan bahwa seluruh variabel dependen memiliki hubungan dengan variabel independen. Hal ini berarti bahwa tata letak, keterlihatan (visibility), pengenalan fitur, kelengkapan fitur dan kemudahan menggunakan fitur merupakan komponen yang berhubungan dengan penilaian individu terhadap kualitas aplikasi ujian online berbasis Excel yang diuji pada penelitian ini.

\section{Pembahasan}

Suatu proyek perangkat lunak harus memiliki performa yang baik (Hidayati, Anita, dkk, 2017) dan Kualitas perangkat lunak merupakan salah satu aspek yang penting dalam pengembangan suatu software (Basu, Anirban, 2015). Terdapat beberapa pendekatan yang dapat dilakukan untuk melakukan pengukuran kualitas suatu perangkat lunak, antara lain seperti pendekatan pengukuran perangkat lunak dari McCall model klasik yang terdiri dari 11 faktor. Model yang lain terdiri dari 12 sampai 15 faktor yang dikemukakan oleh Deutsch dan Willis dan oleh Evans dan Marciniak (Hidayati, Anita, dkk, 2017). Model kualitas McCall pada faktor operasi produk berisi aspek (1) Correctness, yaitu Tingkat pemenuhan program terhadap kebutuhan yang dispesifikasikan dan memenuhi tujuan/misi pelanggan sudah benar (2) Reliability, yaitu kemampuan aplikasi untuk dapat dijalankan secara berhasil/ tidak gagal dalam eksekusi; atau tingkat kegagalan yang kecil dan tidak mempengaruhi tujuan dari aplikasi (3) Efficiency yaitu kemampuan penggunaan sumber daya secara efisien pada perangkat maupun sistem, seperti efisiensi waktu pemrosesan processor (eksekusi), ataupun pemakaian media penyimpanan (memori, space, bandwidth) yang tidak besar
(4) Usability, yaitu faktor yang memperhatikan aspek kemudahan perangkat lunak untuk digunakan dan dipelajari (Sugiantoro, Bambang dan M. Mustakim. 2017). Usability mempunyai unsur akademis seperti psikologis, ergonomi, dan human factors. (5) Maintainability, yaitu kemudahan dari perangkat lunak untuk dipelihara atau diperbaiki jika terjadi kerusakan. Sebuah perangkat lunak dikatakan dapat dipelihara jika koreksi dari minor bugs tidak memerlukan usaha yang besar. (6) Flexibility, adalah kemudahan dalam membuat perubahan yang dibutuhkan akibat perubahan lingkungan (7) Testability, merupakan kemampuan perangkat lunak untuk diuji. Selain itu testability adalah derajat yang dimiliki sebuah sistem untuk memfasilitasi kriteria pengujian dan performansi dari pengujian tersebut untuk mengukur sejauh mana kriteria tersebut dipenuhi (8) Portability, yaitu ketika biaya untuk memindahkannya (transport dan daptasi) ke lingkungan yang baru lebih kecil jika dibandingkan dengan biaya untuk membangun perangkat lunak tersebut dari awal, (9) Reusability, adalah properti dari perangkat lunak yang memungkinkan perangkat lunak atau modul-modulnya digunakan kembali untuk sistem lain. Suatu perangkat lunak dikatakan memiliki tingkat reusable yang baik jika modul-modulnya dapat digunakan kembali untuk menyusun atau diterapkan pada aplikasi lainnya. (10) Interoperability, adalah kemampuan suatu perangkat lunak untuk bekerja dengan perangkat lainnya tanpa mengalami kesulitan (Mulyanto, Agus. 2016).

Dari sekian banyak aspek pengukuran kualitas, Penelitian ini lebih menekankan pada aspek usabilitas dimana aspek ini memperhatikan sisi personal (human) values dari end user (pengguna) aplikasi tersebut. Usability suatu aplikasi berkaitan dengan seberapa mudah dan intuitif aplikasi tersebut bagi pengguna untuk belajar menggunakan dan berinteraksi dengan aplikasi sehingga dengan cepat dan mudah menyelesaikan tugas mereka. Usability berkaitan dengan atribut easy of use (mudah digunakan) dan usefulness (kegunaan) dari sebuah aplikasi (Fryonanda, Harfebi; Ahmad, Tarmizi, 2017).

Hasil penelitian menunjukkan bahwa Hasil penelitian menunjukkan bahwa seluruh variabel (Tingkat Kemudahan Menjalankan Aplikasi, Kelengkapan Fitur Aplikasi, 
Kemudahan Pengenalan (Rekognisi) Fitur Aplikasi, Keterlihatan (Visibility) Fitur Aplikasi Dan Penilaian Tata Letak) memiliki hubungan yang kuat dengan variabel Penilaian Kualitas Aplikasi; dimana diperoleh besaran korelasi antara tingkat kemudahan menjalankan aplikasi dengan penilaian kualitas sebesar 0,575 (korelasi kuat); keterlihatan (visibility) fitur berhubungan dengan penilaian kualitas aplikasi dengan besar koefisien korelasi 0,563 (korelasi kuat); pengenalan fitur berhubungan dengan penilaian kualitas aplikasi dengan koefisien korelasi 0,556 (korelasi kuat); penilaian atas kelengkapan fitur berhubungan dengan penilaian kualitas aplikasi dengan koefisien korelasi 0,384 (korelasi cukup); dan terdapat hubungan antara kemudahan menggunakan fitur dengan penilaian kualitas aplikasi dengan besaran koefisien korelasi 0,212 (korelasi sangat lemah).

Tata letak adalah pengaturan lokasi dari komponen / fitur dan fasilitas maupun kesesuaian antara tampilan dengan layar yang membuat seseorang dapat mengakses aplikasi secara nyaman dan tidak terdistraksi dengan komponen lain yang tidak diperlukan saat bekerja dengan aplikasi tersebut. Dalam penggunaan teknologi, perlu dibangun suatu user interface (antar muka pengguna) yang baik. User interface merupakan bentuk tampilan grafis yang berhubungan langsung dengan pengguna (user). Antarmuka pengguna berfungsi untuk menghubungkan antara pengguna dengan sistem operasi, sehingga alat tersebut bisa digunakan (Karnita, Rosa, 2011). Tata letak yang baik akan membuat pengguna aplikasi merasa nyaman dan dapat dengan mudah mengenali bagian-bagian dan fungsinya.

Visibilitas meliputi kemudahan untuk melihat bagian-bagian / komponen dari tampilan perangkat; yang meliputi kejelasan tulisan, warna, ukuran dan kontras pada bagian/ fitur tertentu; dan kejelasan serta kenyamanan dalam melihat secara fisik fitur yang ada didalamnya. Terkait dengan hal ini, Preston L. Bannister (2005) dalam Karnita, Rosa (2011), memberikan beberapa rekomendasi yang diungkapkan untuk membuat user interface antara lain: (1) Layar harus memberikan kontras yang baik dan menggunakan huruf yang jelas. (2) Teks yang dibaca tidak boleh bergerak atau berpendar ketika sedang dibaca. (3) Seminimal mungkin terdapat gambar (visual) yang berkedip-kedip atau yang menyorot tiba-tiba. (4) Sediakan penerangan latar yang cukup memadai (5) Teks disediakan dalam tampilan huruf besar dan kecil, tidak huruf kapital semua. (6) Pada layar berwarna, kombinasi merah-hijau dan biru-kuning sebaiknya tidak dipilih. (7) Sediakan warna dengan intensitas yang berbeda sehingga obyek yang berwarna dapat terlihat dengan jelas pada layar hitam putih. Tampilan layar mempengaruhi kenyamanan dari pengguna dan sangat terkait dengan fitur dan program yang ditanamkan pada aplikasi (Karnita, Rosa, 2011).

Fitur, berasal dari kata Feature, yang diartikan sebagai fungsi atau kemampuan khusus dari suatu alat. Namun istikah fitur juga merujuk pada fasilitas tambahan yang disertakan dalan suatu paket produk (Pann, 2019). Kemudahan untuk mengenali fitur dan fasilitas yang terdapat didalamnya merupakan aspek yang penting dimana pengguna dapat dengan mudah merekognisi/ mengenali dari manfaat fitur, mengenali cara penggunaan dan mengetahui bilamana fitur tersebut harus digunakan dalam rangka mencapai tujuan. Fitur utama dalam aplikasi ujian try out uji kompetensi meliputi bagian dari penampil soal ujian, penampil pilihan jawaban dan bagian untuk memilih jawaban. Fitur lain yang memiliki sifat penunjang antara lain : fitur untuk menentukan waktu tersisa (timer coutndown), fitur untuk mengecek soal yang sudah/ belum dikerjakan; dan fitur untuk menunjukkan progres pengerjaan soal.

Kelengkapan fitur merupakan dimensi seberapa banyak fasilitas yang ada pada suatu aplikasi yang dapat digunakan sebagai modal/ bahan bagi seseorang untuk menyelesaikan penggunakan aplikasi untuk mencapai tujuan. Suatu aplikasi dianggap memiliki fitur yang lengkap manakala pengguna dapat mengakses semua fitur yang memudahkan ia menyelesaikan tugas atau mencapai tujuan; atau terdapat fitur yang memungkinkan bantuan ketika mengalami hambatan dalam menyelesaikan tugas/ mencapai tujuannya. Dalam kaitan dengan aplikasi ujian, fitur aplikasi yang membantu memudahkan menyelesaikan soal dengan baik antara lain fitur untuk memilih jawaban, mengganti jawaban, memberikan tanda jika memilih jawaban ragu, fitur untuk melihat progres pengerjaan soal dan fitur untuk mengecek soal yang belum dikerjakan. 
Persepsi Kemudahan Penggunaan (ease of use) merupakan tingkatan dimana seseorang percaya bahwa teknologi mudah untuk dipahami (Irmadhani \& Nugroho, Mahendra Adhi,2012). Kemudahan dalam mengoperasikan suatu perangkat meliputi kemudahan dalam memulai/ start suatu aplikasi, tidak membutuhkan upaya yang berlebihan dan tidak membutuhkan sumber daya yang besar (misalnya membutuhkan waktu loading yang lama, atau harus memasukkan kode atau prosedur khusus) untuk menjalankan aplikasi; kemudahan dalam menyelesaikan tugas dan atau mencapai tujuan dengan menggunakan perangkat / aplikasi tersebut. Dapat dikatakan bahwa kemudahan penggunaan mampu mengurangi usaha seseorang baik waktu maupun tenaga untuk mempelajari sistem atau teknologi karena individu yakin bahwa sistem atau teknologi tersebut mudah untuk dipahami. Intensitas penggunaan dan interaksi antara pengguna (user) dengan sistem juga dapat menunjukkan kemudahan penggunaan. Sistem yang lebih sering digunakan menunjukkan bahwa sistem tersebut lebih dikenal, lebih mudah dioperasikan dan lebih mudah digunakan oleh penggunanya (Adam et al., 1992) dalam Irmadhani \& Nugroho, Mahendra Adhi (2012).

Kualitas perangkat lunak merupakan salah satu aspek yang penting dalam pengembangan suatu software (Basu, Anirban, 2015). Salah satu aspek yang menjadi pengukuran kualitas antara lain adalah aspek usabilitas dimana aspek ini berorientasi pada sisi pengguna akhir dari produk sebagai subyek untuk menilai kualitas dari aplikasi. Aspek kualitas ini memperhatikan sisi personal (human) values dari pengguna aplikasi/ program tersebut. Usability suatu aplikasi berkaitan dengan seberapa mudah aplikasi tersebut dijalankan perlu dikembangkan penelitian lebih lanjut untuk melihat aspek kualitas lain pada aplikasi ujian Try Out Uji Kompetensi berbasis Excel; utamanya pada aspek correctness dan reliabilitas dari aplikasi ujian sebagai indikator apakah aplikasi ini dapat digunakan secara luas

\section{Ucapan Terimakasih}

Terimakasih kepada Asosiasi Institusi Pendidikan Vokasi Keperawatan Indonesia (Aipviki) Jawa Timur serta Stikes Pamenang oleh pengguna dalam kepentingan untuk mencapai tujuannya. Usability berbungan erat dengan atribut easy of use (mudah digunakan) dan usefulness (kegunaan) dari sebuah aplikasi (Fryonanda, Harfebi; Ahmad, Tarmizi, 2017). Hasil penelitian menunjukkan bahwa seluruh variabel independen (Tingkat Kemudahan Menjalankan Aplikasi, Kelengkapan Fitur Aplikasi, Kemudahan Pengenalan (Rekognisi) Fitur Aplikasi, Keterlihatan (Visibility) Fitur Aplikasi Dan Penilaian Tata Letak) memiliki hubungan dengan penilaian terhadap kualitas dari aplikasi. Sebagaimana dipahami bahwa aspekaspek diatas merupakan bagian tidak terpisahkan dari mutu dan penilaian individu atas pengalamannya menggunakan apliasi; variabel independen yang diteliti semuanya merupakan unsur yang berhubungan dengan sisi humanisme dari pengguna.

\section{Kesimpulan}

1. Terdapat hubungan antara penilaian tata letak dengan penilaian kualitas aplikasi Try Out Uji kompetensi berbasis Excel

2. Terdapat hubungan antara penilaian keterlihatan (visibility) aplikasi dengan penilaian kualitas aplikasi Try Out Uji kompetensi berbasis Excel

3. Terdapat hubungan antara penilaian pada pengenalan (rekognisi) fitur dengan penilaian kualitas aplikasi Try Out Uji kompetensi berbasis Excel

4. Terdapat hubungan antara penilaian kelengkapan fitur dengan penilaian kualitas aplikasi Try Out Uji kompetensi berbasis Excel

5. Terdapat hubungan antara penilaian kemudahan penggunaan fitur dengan penilaian kualitas aplikasi Try Out Uji kompetensi berbasis Excel

\section{Saran}

yang telah memfasilitasi penyelenggaraan penelitian.

\section{Daftar Pustaka}

Basu, Anirban. 2015. Software Quality Assurance, Testing And Metric, Deplhi - PHI Learning Private

Fryonanda, Harfebi; Ahmad, Tarmizi .2017. Analisis Website Perguruan Tinggi Berdasarkan Keinginan Search Engine Menggunakan Automated Software Testing Gtmetrix, Kalbiscentia,Volume 4 No. 2 Agustus 2017 
Hartina, Ayu; Tahir, Takdir; Nurdin, Nurhaya ; Djafar , Mudawati .2017, Faktor yang Berhubungan dengan Kelulusan Uji Kompetensi Ners Indonesia (UKNI) di Regional Sulawesi, Jurnal Persatuan Perawat Nasional Indonesia ( JPPNI ) Volume 2, Nomor 2, November 2017

Hidayati, Anita; Oktariza, Elsa ; Rosmaningsih, Fatimah; Lathifah, Suci Ana. 2017. Analisa Kualitas Perangkat Lunak Sistem Informasi Akademik Menggunakan McCall, Jurnal Multinetics Vol 3 No. 1, Mei 2017

Irmadhani \& Nugroho, Mahendra Adhi. 2012, Pengaruh Persepsi Kebermanfaatan, Persepsi Kemudahan Penggunaan Dan Computer Self Efficacy, Terhadap Penggunaan Online Banking Pada Mahasiswa S1 Fakultas Ekonomi Universitas Negeri Yogyakarta, Kajian Pendidikan Akuntansi Indonesia, Vol 1, No 3 (2012)

Karnita, Rosa.2011, Melihat Dan Merasakan Tampilan Grafis Layar Telepon Selular, Jurnal Itenas Rekarupa, Vol 1 No. 1, Maret 2011 pp 85-94

Kemenristekdikti. 2016, Siaran Pers No. 08/SP/HM/BKKP/IV/2016 tentang Implementasi Uji Kompetensi Nasional bidang Kesehatan sebagai Langkah Konkrit Penjaminan Mutu Pendidikan Tinggi Kesehatan, https://www.ristekbrin.go.id/siara n-pers/implementasi-uji-kompetensinasional-bidang-kesehatan-sebagai-langkahkonkrit-penjaminan-mutu-pendidikan-tinggikesehatan/

Mulyanto, Agus. 2016. Pengujian Sistem Informasi Akademik Menggunakan McCall's Software Quality Framework, 17 Juli 2017.

Oducado, R.M.F., \& Penuela, A.C. 2014. Predictors of Academic Performance in Professional Nursing Courses in a Private Nursing School in Kalibo, Aklan, Philippines. Asia Pacific Journal of Education, Arts and Sciences, 1(5): 21-28

Pann, 2019, Fitur-Teknologi Informasi. 14/04/2019, https://glosarium.org/arti-fiturdi-komputer/ diakses pada 25 Nov 2020

Rahadian, D. Z. 2018. Faktor-Faktor Yang Mempengaruhi Kelulusan Uji Kompetensi Mahasiswa Profesi Ners Stikes Jenderal Achmad Yani Yogyakarta. Jurnal Wacana Kesehatan, 2(2)

Septiawan, Fansuri (2020). Efektivitas Penggunaan Google Form Dalam Pembelajaran Daring Pada Mata Pelajaran Pemeliharaan Mesin Sepeda Motor Di Smk Negeri 1 Koba. Jurnal Pendidikan Teknik Mesin Volume 7 nomor 2 (November 2020)

Sugiantoro, Bambang dan M. Mustakim 2017. Analisa Usabilitas Sistem Deteksi Akses Pornografi Pengguna Internet Menggunakan
Metode Mccall'S. Volume 2 No. 1. http://join.if.uinsgd.ac.id/index.php/join/articl e/viewFile/10/60-pdf, 17 Juli 2017

Tamsuri, Anas \& Suryono. 2020, Faktor Yang Berpengaruh Terhadap Sikap Penerimaan Mahasiswa Dalam Penggunaan Media Google Form Pada Try Out Uji Kompetensi, Jurnal Ilmiah Pamenang, Vol.2 No.1 pp 4150

Wardani, Yulia \& Mahayanti, Agnes .2017. Preparation Strategic and Results of Nursing Exam of Nursing Diploma in Indonesia, International Journal of Studies in Nursing; Vol. 3, No. 3 